\title{
Managing the future care burden of stroke
}

\author{
Citation for published version (APA):
}

Ronald W.H., H. (2018). Managing the future care burden of stroke: Evaluation of an integrated care pathway including early hospital discharge with rehabilitation planning in the nursing home. [Doctoral Thesis, Maastricht University]. Datawyse / Universitaire Pers Maastricht. https://doi.org/10.26481/dis.20180628rh

Document status and date:

Published: 01/01/2018

DOI:

10.26481/dis.20180628rh

Document Version:

Publisher's PDF, also known as Version of record

\section{Please check the document version of this publication:}

- A submitted manuscript is the version of the article upon submission and before peer-review. There can be important differences between the submitted version and the official published version of record.

People interested in the research are advised to contact the author for the final version of the publication, or visit the DOI to the publisher's website.

- The final author version and the galley proof are versions of the publication after peer review.

- The final published version features the final layout of the paper including the volume, issue and page numbers.

Link to publication

\footnotetext{
General rights rights.

- You may freely distribute the URL identifying the publication in the public portal. please follow below link for the End User Agreement:

www.umlib.nl/taverne-license

Take down policy

If you believe that this document breaches copyright please contact us at:

repository@maastrichtuniversity.nl

providing details and we will investigate your claim.
}

Copyright and moral rights for the publications made accessible in the public portal are retained by the authors and/or other copyright owners and it is a condition of accessing publications that users recognise and abide by the legal requirements associated with these

- Users may download and print one copy of any publication from the public portal for the purpose of private study or research.

- You may not further distribute the material or use it for any profit-making activity or commercial gain

If the publication is distributed under the terms of Article $25 \mathrm{fa}$ of the Dutch Copyright Act, indicated by the "Taverne" license above, 
Summary 



\section{Summary}

In Chapter 1, a general introduction into the background of this thesis is given. In the thesis an evaluation was performed of a new stroke care model, which combines early hospital discharge to a nursing home with assessment and rehabilitation planning in the nursing home. The hypothesis was that the new stroke model makes care for stroke patients more cost-effective and accessible, without negatively influencing functional outcomes, quality of life or satisfaction with care.

Chapter 2 describes the development towards the new (integrated) stroke care model in the region of Maastricht during the last 15 years. Integration was needed to improve the continuity, coordination and quality of stroke care. In reworking and developing the care process, a redesign took place to emphasize early discharge from hospital and assessing the best individual rehabilitation track in the nursing home. The development and implementation of this new stroke care model in the region of Maastricht led to a shorter length of hospital stay, more patients being directly admitted to the hospital stroke unit and an earlier start of rehabilitation. But the implementation of the new stroke care model also led to some unforeseen problems and lessons learned. As experiences with the first patients showed, in general patients did not associate a nursing home with a quick discharge to their own home, but with a long or even permanent residency. A shift of tasks from hospital professionals to professionals working in the nursing home led to resistance on part of the hospital professionals. Also a better coordination of working hours between employees of the hospital discharge office was needed, by which patient transfers might have been better planned in time.

Chapter 3 describes the design of the non-randomised comparative study evaluating the new model involving early admission to a nursing home, with multidisciplinary assessment, for stroke patients. The design involved a non-randomised comparative trial for two groups. Participants were followed for 6 months from the time of stroke. The intervention consisted of a redesigned care pathway for stroke patients. In this care pathway, patients were to be discharged from hospital to a nursing home within 5 days, in comparison with 10 days in the "care as usual" situation. In the nursing home a structured assessment took place, aimed at planning adequate rehabilitation. People in the control group received usual care, with a less extensive assessment in hospital. The primary outcome measures of the effect evaluation were quality of life and activities of daily life (ADL). Quality of life was measured with a disease specific (SASIP-30) and a generic (EQ-5D-3L) quality of life instrument and ADL by means of the Barthel index (BI). Secondary outcome measures were: instrumental activities of daily living (IADL) measured by means of the Frenchay Activity Index (FAI), handicap(s) measured by means of the Modified Rankin Scale (MRS). Cognitive functioning was measured by means of Mini Mental State Examination (MMSE), Apraxia Test (AT) and Star Cancellation Test (SCT). Anxiety and depression were measured by the Hospital Anxiety and Depression Scale 
(HADS) and the patients' satisfaction with stroke care was measured by means of the Satisfaction with Stroke Care Questionnaire (SASC-19). The strain on caregivers was measured by the Caregivers Strain Index (CSI). Other secondary outcome measures were medical complications occurring within 3 months after stroke. The following diagnoses were regarded as medical complications: a new stroke, epileptic seizures, pneumonia, urinary tract infections, fractures, bedsores, myocardial infarct, heart failure and atrial fibrillation. The data on medical complications was collected from the patients' files. Besides the primary and secondary outcome measures we assessed some background variables which were considered to be predictors, confounders or effect modifiers. The following personal characteristics were assessed: age, sex, socio-economic status, risk factors, co-morbidity, stroke location and stroke severity measured by the National Institute of Health Stroke Scale (NIHSS). All background variables were measured at baseline. In addition, an economic evaluation was performed from a societal perspective and a process evaluation was carried out to evaluate the feasibility of the intervention as well as the experiences and opinions of patients.

Chapter 4 presents the results of the non-randomised comparative study, looking at effects of early hospital discharge and assessment and rehabilitation planning in a nursing home on quality of life, functional outcomes and satisfaction with care. 239 acute stroke patients participated in this study: 122 in the intervention and 117 in the control group. We did not succeed in implementing early discharge from hospital, although the systematic assessment in the nursing home was accomplished. No clinically relevant differences were found between the groups for functional outcomes, quality of life or satisfaction with care. In comparison with the control group, a trend towards reduction in length of nursing home stay was found in the intervention group for those patients that after the assessment got rehab care in the nursing home.

Chapter 5 presents the outcomes of a study to assess the cost-utility and costeffectiveness of the new stroke care model aiming at the early discharge of stroke patients from hospital to a nursing home for systematic assessment and planning rehabilitation. The economic evaluation was embedded in the non-randomised comparative trial for which 239 acute stroke patients were recruited from two stroke services in the regions of Maastricht and Eindhoven. Self-reported costs and quality of life were assessed during a 6-month follow-up period. Quality of life was measured with a disease specific (SASIP-30) and a generic (EQ-5D-3L) quality of life instrument. The economic evaluation was conducted from a societal perspective. Uncertainty was accounted for by bootstrapping and sensitivity analyses. Overall costs were higher in the intervention group (I: mean= $€ 22009,95 \% \mathrm{Cl}: 21720,22298$; C: mean= $€ 19769,95 \% \mathrm{Cl}$ : 19430, 20108). The cost-utility analyses, using generic quality of life as the outcome measure, showed that the new model for stroke care was more efficient, at a Willingness to Pay threshold of $€ 50,000$ per Quality Adjusted Life Year (QALY). Using disease-specific quality of life as an outcome measure, the cost-effectiveness analyses showed that the new 
stroke care model was more effective and more expensive in comparison with care as usual. To our knowledge this is the first study to determine the cost-utility and costeffectiveness of a stroke service aimed at early hospital discharge with subsequent assessment and rehabilitation planning in a nursing home. With a willingness to pay 50,000 euros for a Quality Adjusted life Year gained, the new stroke care model proved, with a probability of $76 \%$ to be more cost effective.

Chapter 6 presents the outcomes of a qualitative study, to explore stroke patients' experiences with and their opinions on this newly developed stroke care model. A qualitative study among stroke patients admitted to the Maastricht University Medical Centre between September 2010 and January 2011, who underwent a multidisciplinary assessment in a nursing home as part of a newly developed stroke care model. Each link (hospital stay, transfer to and stay in the nursing home and return home) of this new care model was assessed by means of semi-structured interviews. Fourteen interviews were performed. Stroke patients stated that in general everything was well cared for and organised. They did not experience distorting problems with the care delivery. However, more attention has to be paid to the communication with the patients and their partners concerning the rehabilitation track.

Chapter 7 concerns the general discussion of the thesis and provides an overview of the main findings. Theoretical considerations, methodological considerations and also recommendations for both daily practice and future research are presented. 

Samenvatting 



\section{Samenvatting}

Hoofdstuk 1 geeft een algemene inleiding in de achtergronden van dit proefschrift. In het proefschrift wordt een nieuw zorgmodel geëvalueerd, dat een vroeg ontslag uit het ziekenhuis combineert met het beoordelen van het revalidatiepotentieel en revalidatieplanning in het verpleeghuis. De hypothese is dat dit nieuwe zorgmodel de zorg voor patiënten met een beroerte kosteneffectiever en toegankelijker maakt, zonder dat het functioneren, de kwaliteit van leven of de tevredenheid met de geleverde zorg afnemen.

In hoofdstuk 2 worden de ontwikkelingen beschreven die, gedurende de afgelopen 15 jaar hebben geleid tot het ontstaan van het nieuwe zorgmodel voor patiënten met een beroerte, in de regio Maastricht. Integratie was nodig om de continuïteit, coördinatie en kwaliteit van de zorg voor patiënten met een beroerte te verbeteren. Daartoe heeft er een herontwerp van het zorgproces plaatsgevonden, waarbij de nadruk ligt op vroeg ontslag uit het ziekenhuis en vervolgens de inschatting van het beste individuele revalidatietraject in het verpleeghuis plaatsvindt. De ontwikkeling en invoering van dit nieuwe zorgmodel in de regio Maastricht heeft geleid tot een kortere opnameduur in het ziekenhuis. Ook konden meer patiënten rechtstreeks op de stroke unit worden opgenomen en starten er meer vroegtijdiger met hun revalidatie. Maar de invoering van dit nieuwe zorgmodel leidde ook tot enkele onvoorziene problemen en leermomenten. Zoals de ervaringen met de eerste patiënten toonden, associëren velen van hen een verpleeghuis niet met een snel ontslag naar huis maar eerder met een lang of soms zelfs permanent verblijf. De verschuiving van taken, van ziekenhuisprofessionals naar professionals die in een verpleeghuis werken, leidde bovendien tot verzet van de kant van de ziekenhuisprofessionals. Verder was er een betere afstemming van de werktijden van medewerkers van het ontslagbureau in het ziekenhuis nodig, zodat overplaatsingen beter gepland konden worden.

In hoofdstuk 3 wordt een beschrijving gegeven van de vergelijkende studie naar de effecten van het nieuwe zorgmodel voor patiënten met een beroerte. Het design betrof een niet gerandomiseerde vergelijkende studie voor twee groepen. De proefpersonen werden na de beroerte 6 maanden gevolgd. De interventie bestond uit het volgen van het nieuw vormgegeven zorgpad voor patiënten met een beroerte. Patiënten zouden binnen 5 dagen van het ziekenhuis naar het verpleeghuis worden ontslagen, in vergelijking met 10 dagen bij de controlegroep. In het verpleeghuis vond een gestructureerd assessment plaats, gericht op een adequate revalidatieplanning met nadien starten van het geïndiceerde revalidatietraject. De mensen in de controle groep kregen de gebruikelijke zorg, inhoudende een minder intensief assessment gedurende de in principe langere ziekenhuisopname met vervolgens starten van het geïndiceerde revalidatietraject. De primaire uitkomstmaten van de effectevaluatie waren Kwaliteit van Leven en Activiteiten van het Dagelijks Leven (ADL). De Kwaliteit van Leven werd zowel gemeten 
met een ziekte specifiek (SASIP-30) als een generiek (EQ-5D-3L) Kwaliteit van Leven instrument en de ADL functies werden gemeten met de Barthel index (BI). De secundaire uitkomstmaten waren: instrumentele activiteiten van het dagelijks leven (IADL) gemeten met de Frenchay Activity Index (FAI), handicap(s) gemeten door middel van de Modified Rankin Scale (MRS). Het cognitieve functioneren werd gemeten met de Mini Mental state Examination (MMSE), Apraxia Test (AT) en de Star Cancellation Test (SCT). Angst en depressie werden gemeten met de Hospital Anxiety and Depression Scale (HADS) en de patiënttevredenheid met de geleverde zorg werd gemeten met de Satisfaction with Stroke Care Questionnaire (SASC-19). De druk op de mantelzorg werd gemeten met de Caregivers Strain Index (CSI).

Andere secundaire uitkomstmaten waren medische complicaties, ontstaan in de eerste drie maanden na de beroerte. De volgende diagnoses werden daarbij gezien als medische complicaties: een recidief beroerte, epileptische insulten, luchtweginfecties, urineweginfecties, fracturen, decubitus, myocard infarct, hartfalen en atriumfibrilleren. De gegevens over de medische complicaties werden verzameld uit de medische dossiers. Behalve de primaire en secundaire uitkomstmaten werden relevante achtergrondvariabelen verzameld, die als predictors, confounders en effectmodifiers konden worden beschouwd. De volgende persoonlijke kenmerken werden onderzocht: leeftijd, geslacht, sociaal economische status, co-morbiditeit, locatie en ernst van de beroerte gemeten met de National Institute of Health Stroke Scale (NIHSS). Alle achtergrondvariabelen werden ten tijde van de nulmeting verzameld. Aanvullend werden ook een economische evaluatie uitgevoerd vanuit een maatschappelijk perspectief en een procesevaluatie om de haalbaarheid van de interventie alsook de ervaringen en meningen van de patiënten te evalueren.

In hoofdstuk 4 worden de resultaten beschreven van de niet gerandomiseerde vergelijkende studie naar de effecten van vroeg ontslag uit het ziekenhuis met assessment en revalidatieplanning in het verpleeghuis op de kwaliteit van leven, functionaliteit en tevredenheid met de geboden zorg. Er participeerden 239 patiënten met een acute beroerte in de studie, gerekruteerd van twee stroke services in de regio Maastricht en Eindhoven : 122 in de interventie groep en 117 in de controle groep. Hoewel de invoering van het systematisch assessment in het verpleeghuis is gelukt, lukte het niet om patiënten eerder vanuit het ziekenhuis te ontslaan. Er werden geen klinisch relevante verschillen gevonden tussen de groepen betreffende functionaliteit, kwaliteit van leven of tevredenheid met de geboden zorg. In vergelijking met de controlegroep werd er wel een trend ten aanzien van een vermindering van opnameduur in het ziekenhuis gezien bij die patiënten die na het assessment in het verpleeghuis revalideerden.

In hoofdstuk 5 worden de resultaten beschreven van de economische evaluatie van het nieuwe zorgmodel. De economische evaluatie was onderdeel van de niet gerandomiseerde vergelijkende studie, zoals beschreven in hoofdstuk 4. Gegevens over zelf gerapporteerde kosten en kwaliteit van leven werden gedurende een periode van 6 
maanden verzameld. Kwaliteit van Leven werd met een ziekte specifiek (SASIP-30) en een generiek (EQ-5D-3L) Kwaliteit van Leven instrument gemeten. De economische evaluatie werd vanuit een maatschappelijk perspectief uitgevoerd. Onzekerheid werd middels bootstrapping en sensiviteitsanalyses gecorrigeerd. De totale kosten waren in de interventiegroep hoger (Interventie groep: mean=22009 euro, 95\%Cl: 21720, 22298; Controle groep: mean=19769 euro, 95\%Cl: 19430, 20108). De kostenutiliteitsanalyse, waarbij gebruik werd gemaakt van een generiek Kwaliteit van Leven instrument liet zien dat het nieuwe zorgmodel efficiënter was bij een "willingness to pay" van 50.000 euro per Quality Adjusted Life Year (QALY). Gebruik makende van een ziekte specifiek Kwaliteit van Leven instrument liet de kosteneffectiviteitsanalyse zien dat het nieuwe zorgmodel effectiever en duurder was dan gebruikelijke zorg. Voor zover wij weten is dit de eerste studie die de kostenutiliteit en kosteneffectiviteit van een zorgmodel gericht op vroeg ontslag uit een ziekenhuis met assessment en revalidatieplanning in een verpleeghuis onderzocht. Met een "willingness to pay" van 50.000 euro voor een gewonnen Quality Adjusted life Year, is het nieuwe zorgmodel voor patiënten met een beroerte, met een waarschijnlijkheid van $76 \%$, kosteneffectiever. Echter op basis van deze studie alleen kunnen wij geen definitief antwoord geven op de vraag of het nieuwe zorgmodel een goede investering is.

In hoofdstuk 6 worden de resultaten gepresenteerd van een kwalitatieve studie naar de ervaringen van patiënten met het nieuwe zorgmodel. De kwalitatieve studie werd uitgevoerd onder patiënten die tussen september 2010 en januari 2011 in het Maastricht Universitair Medisch Centrum werden opgenomen na een beroerte en daarna een multidisciplinair assessment ondergingen in het verpleeghuis, als onderdeel van het nieuw ontwikkelde zorgmodel voor patiënten met een beroerte. Elk onderdeel van het zorgmodel (ziekenhuisverblijf, overplaatsing naar en verblijf in het verpleeghuis en ontslag naar huis) werd via semi-gestructureerde interviews onderzocht. Er werden 14 interviews afgenomen. De patiënten gaven aan dat over het algemeen alles goed verzorgd en georganiseerd was. Zij ervoeren geen onoverkomelijke problemen met de zorgverlening in het totale zorgtraject. Er zou echter nog? meer aandacht moeten zijn voor de communicatie met de patiënt en hun mantelzorgers over het verloop en de inhoud? van het revalidatieproces.

Hoofdstuk 7 betreft de algemene discussie van het proefschrift en laat een overzicht zien van de voornaamste bevindingen. Theoretische overwegingen, methodologische overwegingen en aanbevelingen voor de dagelijkse praktijk worden in dit hoofdstuk gepresenteerd. 